\title{
China's Accession to the World Trade Organization: Implications for the Korean Economy
}

\author{
Jong Eun Lee \\ Sejong University \\ Jong-Wha Lee \\ Korea University and Australian National University
}

\begin{abstract}
This paper is exploring the impact on the two proximate economies, Korea and China, of China's accession to the World Trade Organization. We try to figure out how the aggregate effects, export performance, domestic production, and flows of foreign direct investments can be affected by this exciting event, using computable general equilibrium approach. Compared to great beneficial effects on China, the impact on the Korean economy would be marginal. In textiles, wearing apparels, and automobiles, Korea's export to China is likely to increase while there may be small effect on the exports of electronics, chemicals, and machinery. Both China and Korea would benefit from the inflows of international direct investments on the global scale, but they can be fiercer competitors in attracting foreign investors with China's membership in the World Trade Organization as a turning point.

- JEL Classification: C53, D58, F15, F21

- Key Words: China's Accession to the World Trade Organization, Korea, Trade, Capital Accumulation, Foreign Direct Investment

\footnotetext{
*Corresponding address: Jong Eun LEE, Department of Economics, Sejong University, 98 Kunja-Dong, Kwangjin-Gu, Seoul, 143-747, Korea. Tel: +82-2-3408-3137, Fax: +82-2-3408-3338, Email: ljongeun@ sejong.ac.kr; Jong-Wha LEE, Department of Economics, Korea University, Tel: +82-2-32902216, Fax: +82-2-928-4948, Email: jongwha@korea.ac.kr, also Professor, Economics Division, APSEM \& RSPAS, Australian National University, Canberra ACT 0200, Australia, Tel: +61-2-61259786, Fax: +61-2-6125-3700, Email: lee.jong @ anu.edu.au (c)2002-Center for International Economics, Sejong Institution, All Rights Reserved.
} 


\section{Introduction}

The world is about to witness the impacts of China's entry to the World Trade Organization (WTO). A substantial part of China's accession to the WTO has been completed through the successful bilateral negotiations between China and WTO members including the United States, and finally her entry was acknowledged at the Ministerial Conference of WTO that was held in Doha, Qatar in November 2001.

China's accession to the WTO is expected to have significant impacts on both the Chinese and the world economy. China has made great progress in trade liberalization for the last two decades. Her greater openness and integration into the world economy has contributed to the prosperity of both China and its trading partners. By further eliminating trade distortions this time, China will again improve the efficiency of the economy and foster investment inflows. Consequently the Chinese economy will continue to grow fast, which can in turn boost the world trade and output considerably.

This paper analyzes the impact of the China's forthcoming entry to the WTO on her close neighbor, the Korean economy. China and South Korea (henceforth, Korea) have been important trading partners of each other; the bilateral trade and investment flows between two countries have increased over time; Further, the geographical proximity will guarantee transportation advantages between two countries. Cultural and historical ties will become additional advantages. The China's WTO entry and resulting liberalization is expected to make the access of Korean products to the Chinese market easier, and thereby to contribute to Korea's export and output growth; on the other hand, China's increased competitiveness may hurt Korean exports in the world market, where they have been major competitors in a number of sectors.

The nature of the China-Korea trade relationship have multilateral complexity with the rest of the world and the impacts of China's trade liberalization on the Korean economy would differ across industry. In this regard, we employ a multicountry multi-sector computable general equilibrium model in order to estimate the impacts of China's trade liberalization on the Korean economy at the disaggregated industry level. Our analysis is based on a recent version of the Global Trade Analysis Project (GTAP) model. We calibrate the model into 8 regions including China, Korea, Japan, ASEAN, NAFTA, EU, the rest of WTO countries, and non-WTO countries. Each country or region has 30 sectors. We 
provide detailed projections for the changes in the trade and production of the Chinese and Korean economy that will be incurred by the reduction of China's protection over the next five years following her entry into the WTO. A number of recent papers including Wang (1999) and Ianchovichina and Martin (2001) adopted the same computable general equilibrium approach, but focused on assessing the effects of the China's WTO entry on either the Chinese economy alone or the world economy as a whole. A few papers written in Korean analyzed the impacts of the China's WTO entry on the Korean economy (see Yang, 2000, and Cheong, 2001). Cheong (2001) carries out simulations on the effects of China's further tariff reduction and shows that China's trade liberalization will be most beneficial to the Chinese economy and Korea's economic gain will be relatively smaller. Our model and simulation design closely follow his, but we add another important aspect of the China's WTO accession by taking account of the abolition of quotas on the Chinese textile and clothing in the developed country market.

The paper also discusses the implications of the China's WTO entry for the flow of international direct investment in Asia. Particularly for China, relatively high savings and capital accumulations are expected. China's accession to the WTO will have important effects on the Korean economy not only by stimulating Koreas investment to China but also diverting international foreign direct investment (FDI) inflows from Korea to China.

\section{The Overview of the Korea-China Trade Relationship}

China and Korea have been important trading partners of each other since 1992

Table 1. Korea's Trade with China, 1992-2000

(billion US \$, \% in total)

\begin{tabular}{|c|c|c|c|c|c|c|c|c|}
\hline & \multicolumn{2}{|c|}{ Korea's Total Trade } & \multicolumn{2}{|c|}{ Korea's Total Exports } & \multicolumn{2}{|c|}{ Korea's Total Imports } & \multicolumn{2}{|c|}{ Korea's Trade Balance } \\
\hline & with China & $\%$ & to China & $\%$ & from China & $\%$ & with World & with China \\
\hline 1992 & 6.4 & 4.0 & 2.7 & 3.5 & 3.7 & 4.6 & -5.1 & -1.0 \\
\hline 1993 & 9.1 & 5.5 & 5.2 & 6.3 & 3.9 & 4.7 & -1.6 & 1.3 \\
\hline 1994 & 11.7 & 5.9 & 6.2 & 6.5 & 5.5 & 5.3 & -6.3 & 0.7 \\
\hline 1995 & 16.6 & 6.4 & 9.1 & 7.3 & 7.4 & 5.5 & -10.1 & 1.7 \\
\hline 1996 & 19.9 & 7.1 & 11.4 & 8.8 & 8.5 & 5.7 & -20.6 & 2.9 \\
\hline 1997 & 23.7 & 8.4 & 13.6 & 10.0 & 10.1 & 7.0 & -8.5 & 3.5 \\
\hline 1998 & 18.4 & 8.2 & 11.9 & 9.0 & 6.5 & 7.0 & 39.0 & 5.4 \\
\hline 1999 & 22.6 & 8.6 & 13.7 & 9.5 & 8.9 & 7.4 & 23.9 & 4.8 \\
\hline 2000 & 31.4 & 9.4 & 18.6 & 10.8 & 12.8 & 8.0 & 11.8 & 5.8 \\
\hline
\end{tabular}

Source: Korea Customs Service. 
136China's Accession to the World Trade Organization: Implications for the Korean Economy

Table 2. China's Trade with Korea, 1992-2000

(billion US \$, \% in total)

\begin{tabular}{|c|cc|cc|cc|rc|}
\hline & \multicolumn{2}{|c|}{ China's Total Trade } & \multicolumn{2}{c|}{ China's Total Exports } & \multicolumn{2}{c|}{ China's Total Imports } & \multicolumn{2}{c|}{ China's Trade Balance } \\
\cline { 2 - 9 } & with Korea & $\%$ & to Korea & $\%$ & from Korea & $\%$ & with World & with Korea \\
\hline 1992 & 5.1 & 3.1 & 2.4 & 2.9 & 2.6 & 3.3 & 4.4 & -0.2 \\
1993 & 8.2 & 4.2 & 2.9 & 3.1 & 5.4 & 5.2 & -12.2 & -2.5 \\
1994 & 11.7 & 4.9 & 4.4 & 3.6 & 7.3 & 6.3 & 5.4 & -2.9 \\
1995 & 17.0 & 6.0 & 6.7 & 4.5 & 10.3 & 7.8 & 16.7 & -3.6 \\
1996 & 20.0 & 6.9 & 7.5 & 5.0 & 12.5 & 9.0 & 12.2 & -5.0 \\
1997 & 24.1 & 7.4 & 9.1 & 5.0 & 14.9 & 10.5 & 40.4 & -5.8 \\
1998 & 21.2 & 6.5 & 6.2 & 3.4 & 15.0 & 10.7 & 43.4 & -8.8 \\
1999 & 25.1 & 6.9 & 7.8 & 4.0 & 17.2 & 10.4 & 29.4 & -9.4 \\
2000 & 34.5 & 7.3 & 11.3 & 4.5 & 23.2 & 10.3 & 24.1 & -11.9 \\
\hline
\end{tabular}

Source: China's Customs Statistics.

when they normalized diplomatic relationship. China is the third largest trading partner for Korea, while Korea is the fourth largest trading partners for China.

In 2000, Korea's export to China was 18.6 billion US dollars, amounting to about $10.8 \%$ of Korea's total exports (see Table 1). Korea's import from China was 12.8 billion US dollars in 2000, which amounted to $8.0 \%$ of Korea's total imports. China's share in Korea's total external trade (exports and imports) has steadily increased over the $1990 \mathrm{~s}$, from $4.0 \%$ in 1992 to $9.4 \%$ in 2000.

After the United States, China has been the second largest source of Korea's trade surplus since 1993. Korea's trade surplus against China has increased over time, reaching 5.8 billion US dollars in 2000, which was almost a half of Korea's total trade surplus.

Out of China's total external trade, Korea's share also showed an upward trend, increasing from $3.1 \%$ in 1992 to $7.3 \%$ in 2000. In 2000, China's exports to Korea amounted to about $4.5 \%$ of China's total exports, while Korean exports constituted about $10.3 \%$ of China's total imports.

For the export market in China, major Asian exporters compete with each other. Korea is under heavy competition with other competitors including Japan, Hong Kong, and Taiwan. Table 3 shows that Korea's main exports to China include electrical machinery and parts (21.9\% of total Korea's exports to China), organic chemicals $(9.2 \%)$, mineral fuels and oils $(8.7 \%)$, general machinery and parts $(8.6 \%)$, and iron and steel $(7.8 \%)$. For all these products, Japan is the major competitor for Korea. For plastic products, which is Korea's another major export item constituting $11.3 \%$ of total exports to China, Korea competes against Taiwan 
Table 3. Koreas main exports and market share in China in 2000

(million US dollars, \%)

\begin{tabular}{|c|c|c|c|c|c|c|c|c|}
\hline \multirow{2}{*}{ Commodities } & \multicolumn{2}{|c|}{ Exports by Korea } & \multicolumn{6}{|c|}{ Market Share in China's Total Imports } \\
\hline & Value & Share & Korea & USA & Japan & Taiwan & SSEAN & Iong Kong \\
\hline Total & 23207.9 & 100 & 10.3 & 9.9 & 18.4 & 11.3 & 7.1 & 4.2 \\
\hline $\begin{array}{l}\text { Electrical } \\
\text { machinery (85) }\end{array}$ & 5088.9 & 21.93 & 10.0 & 9.3 & 25.0 & 12.6 & 7.9 & 6.3 \\
\hline Plastics (39) & 2632.5 & 11.34 & 18.2 & 7.7 & 17.9 & 24.7 & 7.9 & 4.5 \\
\hline $\begin{array}{l}\text { Organic Chemicals } \\
\text { (29) }\end{array}$ & 2136.2 & 9.20 & 25.7 & 10.2 & 23.1 & 7.0 & 5.7 & 0.3 \\
\hline $\begin{array}{l}\text { Mineral fuels } \\
\text { nd oils (27) }\end{array}$ & 2015.9 & 8.69 & 9.8 & 0.5 & 1.1 & 0.5 & 9.1 & 0.7 \\
\hline $\begin{array}{l}\text { General machinery } \\
\text { (84) }\end{array}$ & 1989.4 & 8.57 & 5.8 & 13.1 & 23.7 & 12.3 & 6.5 & 2.5 \\
\hline Iron and Steel (72) & 1818.3 & 7.83 & 19.0 & 1.4 & 29.3 & 19.6 & 2.1 & 1.2 \\
\hline $\begin{array}{l}\text { Man-made } \\
\text { filaments (54) }\end{array}$ & 996.9 & 4.30 & 27.4 & 1.2 & 22.2 & 34.8 & 4.0 & 6.1 \\
\hline $\begin{array}{l}\text { Raw hides, Leather } \\
\text { (41) }\end{array}$ & 867.5 & 3.74 & 29.4 & 12.4 & 1.9 & 17.5 & 2.3 & 2.4 \\
\hline Paper products (48) & 769.8 & 3.32 & 19.4 & 15.0 & 12.7 & 10.5 & 13.8 & 6.0 \\
\hline $\begin{array}{l}\text { Man-made Staple } \\
\text { Fibers (55) }\end{array}$ & 734.1 & 3.16 & 23.6 & 4.2 & 26.5 & 18.7 & 5.2 & 6.3 \\
\hline $\begin{array}{l}\text { Copper products } \\
\text { (74) }\end{array}$ & 443.6 & 1.91 & 9.5 & 10.0 & 14.2 & 15.7 & 5.5 & 4.4 \\
\hline Textiles (59) & 402.5 & 1.73 & 34.0 & 2.2 & 9.3 & 41.0 & 1.1 & 5.4 \\
\hline $\begin{array}{l}\text { Knitted Fabrics } \\
(60)\end{array}$ & 378.7 & 1.63 & 28.3 & 0.7 & 11.1 & 30.4 & 0.4 & 15.1 \\
\hline $\begin{array}{l}\text { Optical, Measuring } \\
\text { Equip.(90) }\end{array}$ & 256.1 & 1.10 & 3.5 & 21.7 & 33.3 & 6.8 & 2.2 & 6.7 \\
\hline $\begin{array}{l}\text { Aluminum } \\
\text { products (76) }\end{array}$ & 225.9 & 0.97 & 7.0 & 9.0 & 10.4 & 10.9 & 2.6 & 4.1 \\
\hline
\end{tabular}

Source: China's Custom Statistics.

as well as Japan. For mineral fuels and oils constituting $8.7 \%$ of Korea's total exports to China, Korea keeps the largest market share of $9.8 \%$ and competes against ASEAN countries.

As China has steadily increased her export competitiveness, especially in laborintensive manufacturing products, Korea has been losing her advantage in both the Chinese and the world market. The competition between two countries in the world market has become more ferocious in the 1990s. In the United States, which is the largest export market for both China and Korea, China's market share has increased rapidly from $2.9 \%$ in 1989 to $8.2 \%$ in 2000, while Korea has lost its share from $4.3 \%$ 
138China's Accession to the World Trade Organization: Implications for the Korean Economy

Table 4. Major Export Commodities of China and Korea with the Revealed Comparative Advantage Index in 1999

\begin{tabular}{|c|c|c|c|c|}
\hline \multirow[t]{2}{*}{ COMMODITY (HS Code) } & \multicolumn{2}{|c|}{$\begin{array}{l}\text { Share of Total } \\
\text { Exports by }\end{array}$} & \multicolumn{2}{|c|}{$\begin{array}{c}\text { RCA Index } \\
\text { (in the U.S. market) }\end{array}$} \\
\hline & Korea & China & Korea & China \\
\hline CLOTHING ACCESSORIES (61 62) & 3.4 & 14.2 & 1.3 & 1.4 \\
\hline TEXTILE FABRICS $(50 \sim 55,58 \sim 60)$ & 7.3 & 5.0 & 3.3 & 0.7 \\
\hline SILK (50) & 0.1 & 0.4 & 3.4 & 3.1 \\
\hline WOOL AND WOVEN FABRIC (51) & 0.1 & 0.5 & 1.0 & 0.3 \\
\hline COTTON (52) & 0.5 & 1.6 & 1.0 & 1.2 \\
\hline OTHER TEXTILE FIBRES, PAPER YARN (53) & 0.0 & 0.2 & 0.3 & 1.6 \\
\hline MAN-MADE FILAMENTS (54) & 3.1 & 0.4 & 5.1 & 0.1 \\
\hline MAN-MADE STAPLE FIBERS (55) & 0.8 & 1.0 & 3.1 & 0.6 \\
\hline SPECIAL WOVEN FABRICS; LACE (58) & 0.4 & 0.3 & 2.9 & 1.2 \\
\hline IMPREG., COATED TEXTILE FABRICS (59) & 0.8 & 0.1 & 2.5 & 0.1 \\
\hline KNITTED OR CROCHETED FABRICS (60) & 1.4 & 0.5 & 7.4 & 0.1 \\
\hline ELECTRICAL MACHINERY AND EQUIP. (85) & 27.8 & 16.9 & 2.6 & 1.3 \\
\hline ELECTRIC MOTOR AND GENERATOR (8501) & 0.2 & 0.7 & 1.3 & 1.0 \\
\hline ELECTRONIC DOMESTIC APPLIANCES(8509) & 0.1 & 0.3 & 0.5 & 4.3 \\
\hline APPARATUS FOR LINE TELEPHONY (8517) & 0.5 & 1.2 & 0.2 & 1.8 \\
\hline TURNTABLES, RECORD-PLAYERS (8519) & 0.2 & 0.4 & 0.4 & 4.3 \\
\hline VIDEO RECORDERS (8521) & 0.5 & 0.4 & 2.4 & 2.2 \\
\hline TRANSMISSION APPARATUS (8525) & 3.2 & 0.6 & 4.9 & 0.6 \\
\hline TELEVISION RECEIVERS (8528) & 1.0 & 0.4 & 0.9 & 0.3 \\
\hline PRINTED CIRCUITS (8534) & 0.4 & 0.5 & 2.4 & 1.0 \\
\hline THERMIONIC VALVES (8540) & 1.8 & 0.2 & 1.0 & 0.1 \\
\hline ELECTRONIC INTEGRATED CIRCU-IT (8542) & 13.6 & 1.0 & 6.4 & 0.2 \\
\hline
\end{tabular}

Source: Yang (1999) from Korea Trade Information Service.

to $3.3 \%$ over the same period. Table 4 shows that in many labor-intensive manufacturing products such as clothing, cotton textiles, and household electrical appliances, China already surpassed that of Korea in the export competitiveness measured by the Revealed Comparative Advantage (RCA) index.

\section{General Equilibrium Analysis of the China's WTO Entry}

\section{A. Brief Description of Computable General Equilibrium Model}

We use the Global Trade Analysis Project (GTAP) model, which is a dynamic Computable General Equilibrium (CGE) model of the global economy. ${ }^{1}$ The

\footnotetext{
${ }^{1}$ The model described here was implemented and solved using GEMPACK(Harrison and Pearson 2000).
} 
Table 5. Classification of Region and Production Sector

\begin{tabular}{|ll|}
\hline Regions & \\
\hline China & NAFTA countries \\
Korea & EU countries \\
Japan & The rest of WTO member countries \\
ASEAN countries & The rest of non-WTO countries \\
\hline Sectors & \\
\hline Agriculture & \\
Seaweeds & \\
Forestry & \\
Fishery & \\
Service & \\
Industrial Sectors & \\
Plant-based fibers & Paper products, publishing \\
Natural synthetic rubber & Petroleum, coal products \\
Coal & Plastic products \\
Oil & Glass ceramic \\
Gas & Ferrous metals \\
Minerals & Non-ferrous metals \\
Processed marine products & Metal products \\
Beverages & Motor vehicles and parts \\
Textiles & Transport equipment nec \\
Wearing apparel & Electronic equipment \\
Leather products & Machinery and equipment nec \\
Wood products & Manufactures nec \\
& Other industries \\
\hline
\end{tabular}

GTAP model has been widely used to assess the impact of trade liberalization (see Hertel, 1997). Based on the GTAP database version 5, we calibrate the model into 8 regions including China, Korea, Japan, ASEAN, NAFTA, EU, the rest of WTO countries, and the rest of non-WTO countries. Each country or region has 30 sectors including agriculture, seaweeds, fishery, forestry, service and 25 disaggregated industrial sectors (see Table 5).

One of the distinguishing features of the model is that goods are differentiated by region of origin and are modeled as imperfect substitutes. On the demand side this is reflected by the so-called Armington assumption where a constant elasticity of substitution (CES) specification is used to incorporate imperfect substitution between domestically produced goods and imported goods.

In the model, a representative consumer of each region has Cobb-Douglas utility function with respect to three components of final demand-private house- 
140China's Accession to the World Trade Organization: Implications for the Korean Economy

Table 6. China's Tariff Rates and Projected Reduction by Tariff Lines

\begin{tabular}{|c|c|c|c|}
\hline \multicolumn{2}{|c|}{ Tariff Rate in 1999 } & \multicolumn{2}{c|}{ Projected Tariff Rate } \\
\hline Range of Tariff Rates & $\begin{array}{c}\text { Number of Tariff Lines } \\
\text { (\% of total lines) }\end{array}$ & $\begin{array}{c}\text { Projected Reduction } \\
\text { (\% point) }\end{array}$ & $\begin{array}{c}\text { Tariff Rates After } \\
\text { Liberalization }\end{array}$ \\
\hline Over 100 & $9(0.2)$ & 75 & 25 \\
$80-100$ & $22(0.4)$ & 55 & 25 \\
$60-80$ & $32(0.6)$ & $0-60$ & $0-65$ \\
$50-60$ & $23(0.4)$ & $15-40$ & $10-35$ \\
$40-50$ & $46(0.8)$ & $0-37.5$ & $0-40$ \\
$30-40$ & $760(13.4)$ & $0-35$ & $0-30$ \\
$20-30$ & $984(17.3)$ & $0-20$ & $0-28$ \\
$10-20$ & $2167(38.1)$ & $0-18$ & $0-18$ \\
$1-10$ & $1550(27.3)$ & $0-10$ & $0-10$ \\
0 & $92(1.6)$ & 0 & 0 \\
\hline
\end{tabular}

Notes: The projection assumes that China will lower tariff rates by 2008 based on the bilateral agreement between China and the United States.

Source: Cheong (2001) based on information from the US Trade Representatives.

hold expenditures, government expenditures, and savings- at the upper-tier. Composite demand of domestic and foreign goods is formed as,

$$
C_{i r}=a\left[D_{i r}^{\frac{\sigma_{i}-1}{\sigma_{i}}}+M_{i r}^{\frac{\sigma_{i}-1}{\sigma_{i}}}\right]^{\frac{\sigma_{i}}{\sigma_{i}-1}}
$$

where $\sigma_{i}$ is the elasticity of substitution between domestic and foreign goods in industry or commodity $i, a>0$

All sectors are assumed to be perfectly competitive and operate under constant returns to scale. Each sector's production has a nested structure. At the top level, production is formed by a Leontief-type fixed coefficient function of value added and intermediate inputs,

$$
Q_{j, r}=\min \left[Q V A_{j, r}, I_{i, j, r}\right]
$$

where $Q_{j r}$ is industry output of commodity $j$ in region $r, Q V A_{j r}$ is value-added in industry $j$ of region $r$, and $I_{i j r}$ is demand for commodity $i$ for use in $j$ in region $r$.

Composite intermediate goods, $i$ are aggregated in the CES form with domestic and foreign ones as,

$$
I_{i r}=b\left[I D_{i r}^{\frac{\sigma_{i}-1}{\sigma_{i}}}+I M_{i r}^{\frac{\sigma_{i}-1}{\sigma_{i}}}\right]^{\frac{\sigma_{i}}{\sigma_{i}-1}}
$$

where $b>0, I D_{i r}$ and $I M_{i r}$ denote domestic and foreign intermediate inputs $i$ in 
region $r$ respectively. Firms decide on the sourcing of their imports, and then based on the resulting composite import price, they determine the optimal mix of imported and domestic goods.

Value added is decomposed into labor, capital, land, and natural resources based on the substitution elasticity among these primary inputs.

Labor supply is assumed to be fixed in all regions but move freely across sectors. Capital is also fully mobile across sectors and across regions. The utilitymaximizing consumers save additional income and invest it across the world responding to the return on the capital (Francois et al. [1996]). The capital stock increases until the economy reaches the steady state. The increase of capital stock can be interpreted as the outcome of capital accumulation by foreign direct investment at least partly.

\section{B. Simulation Design}

To assess the implications of the China's WTO entry, we first establish the baseline, which shows an equilibrium status of each economy and the global world with initial production and trade as well as protection structure. We use the GTAP database version 5, so the baseline is calibrated with 1997 data. Then, simulations are carried out given a shock of China's accession to the WTO.

The WTO entry requires China to bring her rules into line with WTO norms in a wide range of areas. The most important stipulation is on the Most Favored Nation (MFN) principle, that is, nondiscrimination between suppliers.

China has already carried out trade liberalization to some degrees prior to its expected accession to the WTO, through bilateral negotiations with other countries. Throughout the 1990s, tariff barriers as well as non-tariff barriers considerably dropped in terms of magnitude and deviations across sectors. According to the World Bank data, China had reduced its average of nominal tariffs rates from $36 \%$ in 1994 to $17.9 \%$ in 1998 . Table 6 shows the structure of tariff rates at total 5,685 tariff lines in 1999 and the scheduled reductions of tariff rates agreed with the United States. As of 1999 most tariff rates are in the range of between 1 and 40\%. According to the bilateral agreement between China and the United States, tariff rates are expected to reduce further by 2008 and the reduction will be relatively larger for the import items that are currently under higher protection.

Table 7 presents the pattern and the level of initial tariff rates- aggregated by sector following our sector classification. It also provides the projection of 
142China's Accession to the World Trade Organization: Implications for the Korean Economy

Table 7. China's Tariff Rates and Projected Reduction Schedule by Sector

\begin{tabular}{|c|c|c|c|}
\hline Industry & Initial Tariff Rate & $\begin{array}{c}\text { Tariff after the } \\
\text { WTO entry }\end{array}$ & $\begin{array}{c}\text { Year of } \\
\text { Implementation }\end{array}$ \\
\hline Plant-based fibers & 6.9 & 4.7 & 2002 \\
\hline Natural synthetic rubber & 24 & 20 & 2002 \\
\hline Seaweeds & 15 & 9.7 & 2004 \\
\hline Forestry & 2.4 & 1.7 & 2002 \\
\hline Fishery & 17.1 & 10.5 & 2005 \\
\hline Coal & 4.4 & 4.4 & 2000 \\
\hline Oil & 3.8 & 3 & 2000 \\
\hline Gas & 7.1 & 5.9 & 2002 \\
\hline Minerals & 5 & 4.3 & 2005 \\
\hline Processed marine products & 22.1 & 11.9 & 2005 \\
\hline Beverages & 63 & 36 & 2005 \\
\hline Textiles & 25.4 & 10.3 & 2005 \\
\hline Wearing apparel & 32.9 & 16.1 & 2005 \\
\hline Leather products & 21.5 & 17.5 & 2005 \\
\hline Wood products & 14.3 & 5.2 & 2005 \\
\hline Paper products, publishing & 14.7 & 5.4 & 2008 \\
\hline Petroleum, coal products & 8 & 5.5 & 2005 \\
\hline Plastic products & 11.4 & 6.9 & 2005 \\
\hline Glass ceramic & 17.8 & 15 & 2004 \\
\hline Ferrous metals & 8.9 & 5.1 & 2004 \\
\hline Non-ferrous metals & 8.1 & 5.5 & 2004 \\
\hline Metal products & 13.7 & 11.4 & 2004 \\
\hline Motor vehicles and parts & 41.3 & 14.7 & 2005 \\
\hline Transport equipment nec & 12.3 & 8.2 & 2005 \\
\hline Electronic equipment & 18.1 & 9 & 2005 \\
\hline Machinery and equipment nec & 15.6 & 10 & 2005 \\
\hline Manufactures nec & 21.8 & 16.4 & 2005 \\
\hline Other industries & 13.9 & 7.2 & 2005 \\
\hline Average & 16.8 & 10.1 & \\
\hline
\end{tabular}

Notes: Initial tariff rates are the estimates of the simple-averaged sectoral tariff rates in 1999. The projected tariff rates after the WTO entry and the schedule of tariff reduction are based on the bilateral agreement between China and the United States.

Source: Cheong (2001) based on information from the US Trade Representatives.

relevant changes of the tariff rates based on the agreement between China and the United States. China has relatively high tariff protection on beverages $(63 \%)$, motor vehicles and parts (41.3\%), wearing apparel (32.9\%), and textiles $(25.4 \%)$. These sectors will undergo substantial liberalization. Until 2005, for example, tariff on motor vehicles will lower to $14.7 \%$, and tariff on wearing apparel to 
$16.1 \%$. In the simulation, we assume that China will reduce the tariff rates by keeping her agreement with the United States over the next five years.

Shocks in this simulation also include the abolition of quotas on the Chinese textile and clothing that will has particularly substantial effects on China. Unlike most other developing country exporters, China has been excluded from the Uruguay Round Agreement on Textiles and Clothing. This means that China has not benefited from the integration of textile and clothing products into GATT. ${ }^{2}$ With the China's WTO accession, all existing quotas on Chinese textile and clothing will be phased out by around 2005, and any special textile safeguards introduced under the agreement by around 2008. This process will pave the way for expansion of China's exports of textiles and clothing. This is one of the most beneficial aspects that the accession will bring to China (Wang, 1999, and Ianchovichina and Martin 2001). ${ }^{3}$ In the simulation, we consider that the US and the EU will eliminate quota on Chinese textiles and wearing products in 2005 . The negotiations of China with key WTO member countries also reached an agreement in the reduction of non-tariff barriers (NTBs) in Chinese service and agricultural sectors. But, in the absence of good information on NTBs, the current version of the paper ignores the effects of the NTB changes. The model sets the values of the tariff equivalent of NTBs at zero in both the baseline and simulation scenarios.

\section{Aggregate and Sectoral Effects of the China's WTO entry}

This paper focuses on the effects on the export and production in China and Korea. The simulation assumes that the reduction of tariff rates by China and elimination of quotas on Chinese textiles by developed countries will be complete by the next five years.

Macroeconomic effects from the China's WTO membership are summarized in Table 8. All regions except ASEAN countries gain from the China's accession to the WTO in terms of real GDP. China is the greatest beneficiary from her entry to the WTO in terms of real GDP. Real GDP increases in China by about 0.9 percent, while the changes of real output in other countries and regions are small. Thus, the improvements of efficiency in China after trade liberalization will be mainly taken by China herself.

\footnotetext{
${ }^{2}$ Abolition of quotas has occurred since 1994(WTO 1994a).

${ }^{3}$ The specific date of quota abolition is not resolved completely since there is the question of "fairness" to treat a latecomer, China, as equally as early comers.
} 
144China's Accession to the World Trade Organization: Implications for the Korean Economy

Table 8. Aggregate Impacts of the China's Entry to the WTO

(percentage change from the baseline, US million dollars)

\begin{tabular}{|lrrrrrrc|}
\hline & $\begin{array}{c}\text { Real GDP } \\
(\%)\end{array}$ & $\begin{array}{c}\text { Prices } \\
(\%)\end{array}$ & \multicolumn{1}{c}{ EV } & $\begin{array}{c}\text { Trade } \\
\text { Balance }\end{array}$ & $\begin{array}{r}\text { Terms of } \\
\text { Trade }\end{array}$ & $\begin{array}{c}\text { Value of } \\
\text { Exports (\%) }\end{array}$ & $\begin{array}{c}\text { Value of } \\
\text { Imports (\%) }\end{array}$ \\
\hline Korea & 0.07 & -0.06 & 187.0 & 6859.5 & 0 & 1.86 & 0.11 \\
China & 0.85 & -0.48 & 2016.8 & 9434.7 & -2.1 & 9 & 1.32 \\
ASEAN & -0.1 & -0.12 & -930.4 & -10886.2 & -0.05 & -1.21 & -0.29 \\
NAFTA & 0.1 & 0.01 & 13170.9 & -134681 & 0.44 & -0.55 & 0.67 \\
Japan & 0.02 & -0.09 & -104.3 & 98744.1 & -0.04 & 2.08 & -0.04 \\
EU & 0.1 & -0.05 & 7159.5 & 86019.8 & 0.06 & -0.27 & 0.01 \\
OthWTO & 0.02 & -0.09 & $118.2-90080.6$ & -0.02 & -1.15 & -0.09 \\
NonWTO & 0.02 & -0.08 & 1.19 .0 & 34590.2 & -0.01 & -0.23 & -0.09 \\
\hline
\end{tabular}

Table 8-1. Without Capital Accumulation

(percentage change from the baseline, US million dollars)

\begin{tabular}{|lrrrrrrc|}
\hline & $\begin{array}{c}\text { Real GDP } \\
(\%)\end{array}$ & \multicolumn{1}{c}{$\begin{array}{c}\text { Prices } \\
(\%)\end{array}$} & \multicolumn{1}{c}{ EV } & $\begin{array}{c}\text { Trade } \\
\text { Balance }\end{array}$ & $\begin{array}{r}\text { Terms of } \\
\text { Trade }\end{array}$ & $\begin{array}{c}\text { Value of } \\
\text { Exports }(\%)\end{array}$ & $\begin{array}{c}\text { Value of } \\
\text { Imports }(\%)\end{array}$ \\
\hline Korea & -0.01 & 0.51 & 995.92 & 3757.64 & 0.44 & 0.27 & 0.43 \\
China & 0.49 & 1.63 & 7838.45 & -16103.1 & -0.65 & 3.02 & 3.84 \\
ASEAN & -0.08 & -0.56 & -2144.02 & -6882 & -0.27 & -0.53 & -0.58 \\
NAFTA & 0.01 & -0.38 & 1436.59 & -117893 & 0.17 & 0.1 & 0.01 \\
Japan & 0.01 & 0.22 & 3151.15 & 87577.84 & 0.32 & 0.3 & 0.47 \\
EU & 0.01 & -0.27 & -338.55 & 92717.25 & 0.03 & -0.28 & -0.29 \\
OthWTO & -0.03 & -0.53 & -5201.1 & -78638.3 & -0.25 & -0.57 & -0.75 \\
NonWTO & -0.01 & -0.26 & -681.36 & 35464.06 & -0.06 & -0.2 & -0.26 \\
\hline
\end{tabular}

China is expected to increase her exports by $9 \%$ and imports by $1.3 \%$. Trade balance improves by about $\$ 9.4$ billion, reflecting her higher savings relative to investment.

The aggregate results presented in Table 8-1 are under the fixed capital assumption where there is no capital accumulation effect. For China and Korea, their trade balances in Table 8-1 are aggravated compared to the previous result with capital accumulation shown in Table 8. Therefore China and korea experience the increases of net export increase and capital stock at the same time if considered capital accumulation effect. This is the question of whether trade and foreign direct investment are substitutes or complements even if capital stock increase in our simulation only partly reflects inflows of foreign direct investment.

The Section IV will discuss more on the foreign direct investment issues. From our main result on the aggregate effects shown in Table 8, the overall impact of the China's WTO entry on the Korean economy is not significant at the aggregate 
Table 9. Effects on Sectoral Exports by China and Korea

(percentage change from the baseline)

\begin{tabular}{|c|c|c|c|c|}
\hline & \multicolumn{2}{|c|}{ China's Exports to } & \multicolumn{2}{|c|}{ Korea's Exports to } \\
\hline & World & Korea & World & China \\
\hline Plant-based fibers & 2.95 & 6.12 & -0.41 & 5.43 \\
\hline Natural synthetic rubber & 2 & 1.46 & -10.64 & -42.24 \\
\hline Seaweeds & 3.59 & 8.95 & 8.06 & 18.55 \\
\hline Forestry & -1.45 & -1.21 & 6.8 & 15.83 \\
\hline Fishery & 11.19 & 7.15 & 0.88 & 44.79 \\
\hline Coal & 2.74 & 2.32 & -0.86 & -3.51 \\
\hline Oil & 2.43 & 2.23 & 0 & 0 \\
\hline Gas & -0.24 & 8.63 & 0 & 0 \\
\hline Minerals & -0.4 & -1.6 & 1.14 & 4.51 \\
\hline Processed marine product & 0.98 & 0.25 & 3.83 & 58.38 \\
\hline Beverages & -5.41 & -1.85 & -8.43 & -51.91 \\
\hline Textiles & 13.46 & 3.87 & 15.79 & 54.95 \\
\hline Wearing apparel & 107.45 & 0.34 & -21.95 & 68.04 \\
\hline Leather products & -1.5 & -5.07 & -4.86 & -12.11 \\
\hline Wood products & -1.18 & -0.46 & 3.9 & 27.45 \\
\hline Paper products, publishing & -1.8 & -0.16 & 7.99 & 14.06 \\
\hline Petroleum, coal products & -0.04 & 0.3 & -1.85 & -5.09 \\
\hline Plastic products & -0.28 & 1.94 & 5.21 & 16.58 \\
\hline Glass ceramic & -1.59 & -1.88 & -0.48 & -2.66 \\
\hline Ferrous metals & -2.6 & -1.55 & 3 & 13.21 \\
\hline Non-ferrous metals & -1.74 & -4.17 & -5.51 & -11.99 \\
\hline Metal products & -1.76 & -2.03 & 1.8 & 16.69 \\
\hline Motor vehicles and parts & -4.78 & -0.67 & 1.31 & 119.78 \\
\hline Transport equipment nec & -4.05 & -4.32 & 0.12 & 7.48 \\
\hline Electronic equipment & -3.13 & -3.69 & -0.03 & -1.49 \\
\hline Machinery and equipment & -2.02 & -2.14 & 1.35 & 9.52 \\
\hline Manufactures nec & -0.66 & -1.88 & 3.26 & 31.03 \\
\hline Agriculture & 1.57 & 1.08 & 0.72 & -1.76 \\
\hline Other Industries & -9.83 & -2.1 & 3.77 & 5.09 \\
\hline service & -1.65 & -2.47 & 1.07 & -0.66 \\
\hline
\end{tabular}

level. Real GDP increases by about $0.1 \%$. The expected increase of exports is about $1.9 \%$ from the baseline. The simulation shows that Koreas trade balance improves up to $\$ 6.8$ billion.

Table 9 and 10 present percentage changes in sectoral exports and output in China and Korea resulting from the China's WTO accession. The impact on China's export and output will be most significant in textiles and wearing apparel 
146China's Accession to the World Trade Organization: Implications for the Korean Economy

Table 10. Effects on Sectoral Output

(percentage change from the baseline)

\begin{tabular}{|lrc|}
\hline & Production & \\
\hline Industry & China & Korea \\
\hline Plant-based fibers & 13.39 & 1.98 \\
Natural synthetic rubber & 0.73 & -0.6 \\
Seaweeds & -3.22 & -0.2 \\
Forestry & -1.35 & -0.31 \\
Fishery & -1.71 & -0.29 \\
Coal & -0.59 & 0.1 \\
Oil & -0.45 & 0 \\
Gas & -0.93 & 0 \\
Minerals & -0.46 & 0 \\
Processed marine products & -2.02 & -0.07 \\
Beverages & -4.71 & -0.88 \\
Textiles & 13.87 & 10.46 \\
Wearing apparel & 50.27 & -6.43 \\
Leather products & 0.04 & -3.47 \\
Wood products & -2.61 & 0.34 \\
Paper products, publishing & -1.73 & 0.79 \\
Petroleum, coal products & -1.98 & -0.11 \\
Plastic products & -1.68 & 2.15 \\
Glass ceramic & -0.94 & -0.08 \\
Ferrous metals & -2.7 & 0.88 \\
Non-ferrous metals & -0.18 & -2.47 \\
Metal products & -0.85 & 0.27 \\
Motor vehicles and parts & -5.7 & 0.2 \\
Transport equipment nec & 0.62 & 0.34 \\
Electronic equipment & -1.8 & 0.41 \\
Machinery and equipment nec & -1.1 & -0.28 \\
Manufactures nec & 0.27 & -0.2 \\
Agriculture & -2.52 & \\
Other Industries & 12.77 & \\
Service & -0.69 & \\
\hline & & \\
\hline
\end{tabular}

sectors. In percentage terms, total export of wearing apparel increases by about $107 \%$, and its output by $50 \%$. Because the increase in China's exports is more concentrated in developed countries, Chinese exports to Korea decline in many sectors. Exports increase only slightly in some sectors including seaweeds (9\%), fishery $(7 \%)$, gas $(9 \%)$, and textiles $(4 \%)$.

On the contrary, Korean exports in the Chinese market increase significantly for 
Table 11. Direct Investment by Korean Firms to China, 1988-2001

(number, US million Dollars)

\begin{tabular}{|crrcrrr|}
\hline & \multicolumn{3}{c}{ By Approval } & \multicolumn{3}{c|}{ By Implementation } \\
\cline { 2 - 7 } Year & Case & Amount & $\begin{array}{c}\text { \% in total Korea's } \\
\text { FDI outflows }\end{array}$ & Case & Amount & $\begin{array}{c}\text { \% in total Korea's } \\
\text { FDI outflows }\end{array}$ \\
\hline 1988 & 2 & 3.4 & 0.7 & 0 & 0.0 & 0.0 \\
1989 & 12 & 9.8 & 1.0 & 7 & 6.4 & 1.6 \\
1990 & 39 & 55.6 & 3.5 & 24 & 16.0 & 2.0 \\
1991 & 112 & 84.7 & 5.5 & 69 & 42.5 & 4.1 \\
1992 & 269 & 221.4 & 16.4 & 170 & 140.5 & 12.8 \\
1993 & 631 & 623.2 & 33.2 & 377 & 261.7 & 25.7 \\
1994 & 1065 & 820.7 & 22.9 & 836 & 622.3 & 30.7 \\
1995 & 882 & 1240.6 & 25.1 & 733 & 809.5 & 29.3 \\
1996 & 919 & 1900.1 & 29.2 & 720 & 799.8 & 22.2 \\
1997 & 743 & 907.5 & 15.6 & 606 & 613.1 & 20.5 \\
1998 & 308 & 820.9 & 16.0 & 231 & 619.4 & 18.0 \\
1999 & 541 & 452.6 & 9.8 & 416 & 203.6 & 9.8 \\
2000 & 833 & 657.1 & 13.6 & 683 & 246.0 & 7.1 \\
2001 & 328 & 280.9 & 30.4 & 319 & 50.8 & 14.2 \\
(Jan. -May) & & & & & & \\
\hline
\end{tabular}

Source: The Export-Import Bank of Korea

almost all sectors, especially motor vehicles and parts (120\%), textiles (55\%), and wearing apparel (68\%). Output gains will be large in textiles $(10 \%)$. However, the impacts on Korea's major export commodities are negative or relatively small; Korean exports of electronics to China decrease by about $2 \%$, while the exports of machinery increase by about $10 \%$.

\section{China's WTO Entry and FDI Flows in Asia}

China's WTO entry creates further opportunities for Korea' investment to China. China has been an important host for foreign direct investment, form Korea. Korea's direct investment to China increased continuously since 1988. The amount of approved investment to China peaked at $\$ 1.9$ billion in 1996, amounting about $30 \%$ of total FDI by Korean firms (Table 11). While the investment to China by Korean firms stagnated over the period from 1997 to 1999 due to the financial crisis, it began to recover since 2000 .

The WTO entry will attract more foreign investors from the world to China. Further, the WTO rules on the TRIPS agreements help to facilitate direct 
148China's Accession to the World Trade Organization: Implications for the Korean Economy

Table 12. FDI Inward Stock and Inflows, by Region in 1980-1999

(US million Dollars)

\begin{tabular}{|l|r|r|r|r|r|r|r|}
\hline & \multicolumn{3}{|c|}{ FDI Inward Stock } & \multicolumn{4}{c|}{ FDI Flows } \\
\cline { 2 - 8 } & \multicolumn{1}{|c|}{1980} & \multicolumn{1}{|c|}{1990} & \multicolumn{1}{|c|}{1995} & \multicolumn{1}{c|}{1996} & \multicolumn{1}{c|}{1997} & \multicolumn{1}{c|}{1998} & \multicolumn{1}{c|}{1999} \\
\hline World & 495200 & 1761198 & 2743391 & 377516 & 473052 & 680082 & 865487 \\
Developed countries & 373960 & 1380827 & 1967538 & 219789 & 275229 & 480638 & 636449 \\
Developing countries & 121240 & 377380 & 739499 & 145030 & 178789 & 179481 & 207619 \\
Africa & 19235 & 44104 & 66430 & 5522 & 6896 & 7519 & 8949 \\
Latin America & 44095 & 118300 & 204932 & 45890 & 69172 & 73767 & 90485 \\
Asia & 56587 & 21632 & 461988 & 92434 & 101575 & 96504 & 105621 \\
China & 6252 & 24763 & 137436 & 40180 & 44236 & 43751 & 40400 \\
Hong Kong, China & 22929 & 46826 & 70951 & 10460 & 11368 & 14776 & 23068 \\
India & 1177 & 1593 & 5610 & 2426 & 3577 & 2635 & 2168 \\
Indonesia & 10274 & 38883 & 50601 & 6194 & 4677 & -356 & -3270 \\
Korea & 1140 & 5186 & 9443 & 2308 & 3088 & 5215 & 10340 \\
Malaysia & 5169 & 10318 & 28732 & 7296 & 6513 & 2700 & 3532 \\
Philippines & 1281 & 3268 & 6086 & 1520 & 1249 & 1752 & 737 \\
Singapore & 6203 & 28564 & 59582 & 8984 & 8085 & 5493 & 6984 \\
Taiwan, China & 2405 & 9735 & 15736 & 1864 & 2248 & 222 & 2926 \\
Thailand & 981 & 8209 & 17452 & 2405 & 3732 & 7449 & 6078 \\
\hline
\end{tabular}

Source: UNCTAD, World Investment Report, 2000.

investment to China, the process of applying for direct investment will be further simplified, which will increase the transparency of China. Foreign direct investment to China has increased steadily over the 1980s and 1990s (Table 12). According to the estimates reported in the World Investment Report, total inward FDI stock to China increased from $\$ 6.3$ billion in 1980 to $\$ 24.8$ billion in 1990, and then jumped to $\$ 137.4$ billion in 1995 (which amounted to about $20 \%$ of GDP in China). Among the developing countries China received the largest amount of foreign direct investment, holding over $20 \%$ of total inward FDI stock in developing countries. China continuously attracts the largest amount of direct investment among developing countries. During the period over 1996-1999, annual inflows to China amounted to over $\$ 40$ billion. Other Asian economies including Hong Kong, Korea, Malaysia, and Thailand are also big recipients of FDI inflows in 1990s. More than 50\% of total FDI inflows to developing countries were distributed to Asian countries during the 1996-1999 period. FDI inflows to Korea increased five times over this period, from $\$ 2.3$ billion in 1996 to $\$ 10.3$ billion in 1999. Except China and Hong Kong SAR, Korea received the largest FDI inflows in Asia. 
Table 13. Openness to Foreign Direct Investment, 1995 and 2000

\begin{tabular}{|c|c|c|c|c|}
\hline \multirow{2}{*}{ Ranking } & \multicolumn{2}{|l|}{1995} & \multicolumn{2}{|l|}{2000} \\
\hline & Country & Score & Country & Score \\
\hline 1 & SINGAPORE & 7.993 & SINGAPORE & 8.308 \\
\hline 2 & NEW ZELAND & 7.769 & FINLAND & 8.186 \\
\hline 3 & DENMARK & 7.710 & CANADA & 7.920 \\
\hline 4 & HONG KONG & 7.635 & IRELAND & 7.889 \\
\hline 5 & SWITZERLAND & 7.481 & DENMARK & 7.870 \\
\hline 6 & FINLAND & 7.348 & SWITZERLAND & 7.829 \\
\hline 7 & AUSTRIA & 7.195 & NETHERLANDS & 7.824 \\
\hline 8 & CANADA & 7.190 & ICELAND & 7.710 \\
\hline 9 & NORWAY & 7.121 & NEW ZELAND & 7.706 \\
\hline 10 & AUSTRALIA & 7.089 & AUSTRIA & 7.700 \\
\hline 11 & GERMANY & 7.085 & AUSTRALIA & 7.616 \\
\hline 12 & SWEDEN & 6.970 & NORWAY & 7.478 \\
\hline 13 & USA & 6.909 & USA & 7.439 \\
\hline 14 & ICELAND & 6.779 & GERMANY & 7.433 \\
\hline 15 & ISRAEL & 6.774 & LUXEMBOURG & 7.409 \\
\hline 16 & IRELAND & 6.751 & UK & 7.365 \\
\hline 17 & UK & 6.718 & HONG KONG & 7.307 \\
\hline 18 & NETHERLANDS & 6.670 & SWEDEN & 7.089 \\
\hline 19 & CHILE & 6.608 & ISRAEL & 6.817 \\
\hline 20 & MALYASIA & 6.436 & CHILE & 6.777 \\
\hline 21 & JAPAN & 6.403 & HUNGARY & 6.613 \\
\hline 22 & FRANCE & 6.243 & FRANCE & 6.522 \\
\hline 23 & TAIWAN & 6.219 & JAPAN & 6.434 \\
\hline 24 & BELGIUM & 6.135 & SPAIN & 6.292 \\
\hline 25 & LUXEMBOURG & 6.135 & TAIWAN & 6.208 \\
\hline 26 & PORTUGAL & 5.719 & BELGIUM & 6.201 \\
\hline 27 & THAILAND & 5.691 & TURKEY & 6.171 \\
\hline 28 & SPAIN & 5.544 & MALYASIA & 6.090 \\
\hline 29 & ARGENTINA & 5.244 & GREECE & 6.001 \\
\hline 30 & GREECE & 5.223 & THAILAND & 5.576 \\
\hline 31 & HUNGARY & 5.220 & PORTUGAL & 5.483 \\
\hline 32 & KOREA & 5.194 & CHINA & 5.435 \\
\hline 33 & INDONESIA & 5.009 & MEXICO & 5.381 \\
\hline 34 & CHINA & 4.985 & SOUTH AFRICA & 5.305 \\
\hline 35 & TURKEY & 4.980 & BRAZIL & 5.249 \\
\hline 36 & CZECH REPUBLIC & 4.953 & KOREA & 5.129 \\
\hline 37 & SOUTH AFRICA & 4.876 & PHILIPPINES & 4.969 \\
\hline 38 & BRAZIL & 4.841 & CZECH REPUBLIC & 4.895 \\
\hline 39 & ITALY & 4.784 & INDIA & 4.856 \\
\hline 40 & INDIA & 4.688 & POLAND & 4.754 \\
\hline 41 & PHILIPPINES & 4.548 & ITALY & 4.700 \\
\hline 42 & MEXICO & 4.370 & INDONESIA & 4.524 \\
\hline 43 & COLOMBIA & 4.310 & ARGENTINA & 4.346 \\
\hline 44 & POLAND & 3.946 & SLOVENIA & 4.336 \\
\hline 45 & VENEZUELA & 3.013 & COLOMBIA & 3.910 \\
\hline 46 & RUSSIA & 2.328 & VENEZUELA & 3.738 \\
\hline 47 & SLOVENIA & NA & RUSSIA & 3.464 \\
\hline Average & & 6.019 & & 6.261 \\
\hline
\end{tabular}

Source: World Competitiveness Report. 
Foreign direct investment plays an important role in economic growth. Studies have found that FDI contributes to technology progress in developing countries by increasing inflows of advanced technologies (Borensztein, De Gregorio, and Lee, 1998). China's rapid growth has benefited from huge direct investment inflows that she received.

China will attract more direct investment by improving rules and institutions for FDI after her entry into the WTO. Government policies related to FDI are continuously improved in China. Table 13 presents a measure of FDI openness constructed by the World Competitiveness Report. ${ }^{4}$ According to this measure, China's score increased from 4.98 in 1995 to 5.44 in 2000. In contrast, Korea's FDI openness dropped from 5.19 to 5.13 over the same period. Several studies found that host country's government policy had significant impacts on direct investment by multinational firms (Brianard, 1997, and Taylor, 2000). Thus, it is possible that while the China's WTO entry helps to attract more foreign investors from the world to China, Korea is shunned off from them. It can be harmful on the Korean economy if the China's accession to the WTO diverts international FDI inflows from Korea to China.

\section{Conclusion}

The rapid emergence of China as a world trade power has raised concerns and interests in developed and developing economies alike over her potential impact on the world market and resource reallocations. At the same time, China has the difficult task to adopt trade liberalization measures and to bring her trade regime consistent with WTO rules in order to fulfill her membership requirements at the WTO.

This paper focuses on the economic effects of the China's WTO entry in China and Korea. The simulation from the GTAP model shows that the trade liberalization following the China's WTO entry will be most beneficial to China, but its impacts on the Korean economy will be marginal. There are some sectors such as textiles, wearing apparels, and automobiles that Korea will substantially increase exports to China, but the impacts on Korea's major exports including electronics, chemicals, and machinery will be relatively small.

\footnotetext{
${ }^{4}$ The FDI openness measure is calculated by an average score from the survey questions on restrictions on foreign investment, transparency of regulations, the development of an intellectual property regime, ease of hiring and firing employees, 0and the ease of cross-border ventures.
} 
In terms of foreign direct investment, China's WTO entry will help to stimulate the inflows of international direct investment into China. Korean firms are also likely to increase substantially their direct investment to her neighbor. On the other hand, China's improvement in FDI environments may divert international direct investment away from Korea.

China's prosperity will be certainly beneficial to Korea by expanding the third largest market for her exports. The China's increased competitiveness of trade and investment, however, may hurt the Korean economy unless Korea also continues to improve her competitiveness.

Therefore, for Korea, China will be a good destination for her direct investment as well as one of the strongest competitors for attracting foreign direct investment from the world. On the global scale, however, China and Korea would benefit from capital accumulations in the form of foreign direct investments that could foster their net exports. China's entry to the World Trade Organization would serve as a momentum.

\section{Acknowledgements}

We are grateful to the participants at the conference, "The Impacts of China's WTO Accession on the Asia Pacific Region: Challenges and Policy Implications," September 17-18, 2001, at the East-West Center, Hawaii for helpful comments. Woong Jae Baek and Yunjong Eo provided helpful assistance in data collection.

Date accepted: September 2001

\section{References}

Borensztein, E., J. De Gregorio, and J.W. Lee (1998), "How Does Foreign Direct Investment Afftect Economic Growth," Journal of International Economics, 45, 115135.

Brainard, S.L., (1997), "An Empirical Assessment of the Proximity-Concentration Tradeoff Between Multinational Sales and Trade," American Economic Review, 87, 520-44.

Cheong, I.K. (2001), “The Impacts of China's Accession on China-Japan-Korea Trade Relation, and its Policy Implications for Regional Economic Corporation,” (in Korean), unpublished manuscript, KIEP, Seoul, Korea.

Francois, Joseph F., Bradley J. McDonald, Hakan Nordstrom(1996), “ Liberlization and 
152China's Accession to the World Trade Organization: Implications for the Korean Economy

Capital Accumulation in the GTAP Model", GTAP Technical Paper No. 7

Harrison, W.J., and K.R. Pearson(2000), GEMPACK Documents, Center of Policy Studies and Impact Project, Monash University

Hertel, Thomas W. (1997), (ed.) Global Trade Analysis: Modeling and Applications, Cambridge: Cambridge University Press.

Ianchovichina, Elena, and Will Martin (2001), "Trade Liberalization in Chinaa Accession to the World Trade Organization," mimeo., World Bank.

Taylor, C.T. (2000), "The Impact of Host Country Government Policy on US Multinational Investment Decisions," Word Economy, 635-47.

Wang, Zhi (1999), "The Impacts of China's WTO Entry on the World Labor-Intensive Export Market: A Recursive Dynamic CGE Analysis," World Economy, 379-405.

Yang, P.S. (2000), “The China's Opening Schedule and the Impact on Industries after Joining WTO," (in Korean), KIEPs Official Pool of Regional Experts Series 0011,KIEP, Seoul, Korea. 